\title{
The Effects of Electromagnetic Fields on the Ultrastructure of Heart
}

\author{
Efectos de los Campos Electromagnéticos en la Ultraestructura del Corazón
}

"Sevda Söker;" Cemil Sert; ${ }^{* * * *}$ Mustafa Deniz; ${ }^{* * * *}$ Is s, I Tekmen; *Murat Akkus, \& "Yusuf Nergiz

SÖKER, S.; SERT, C.; DENIZ, M.; TEKMEN, I.; AKKUS, M. \& NERGIZ, Y. The effects of electromagnetic fields on the ultrastructure of heart. Int. J. Morphol., 29(3):960-964, 2011.

SUMMARY: Increasingly the use and convenience of electrical appliances in our daily lives are the cause of harmful effects caused by electromagnetic fields (EMF). The aim of this study was to research the effect of EMF on the ultrastructure of the heart in EMF exposed rats. In this study 45 male Sprague Dawley rats ranging in weight between 260 and 280 grams were used. The rats were divided into 3 groups, control (n:15), Sham (n:15) and EMF group (n: 15) and exposed for 14 days 3 hours per day; gauss levels at 2.5 were applied to the EMF group, while the sham group in the same environment in Plexiglas cage was kept for 14 days 3 hours per day without magnetic field exposure. Control group at 14/10 hours light dark cycle fed in normal cages for 14 days. After two weeks rats were sacrificed by $50 \mathrm{mg} / \mathrm{kg}$ of Ketalar anesthesia and heart tissue fixed in 2.5 gluteraldehide. Routine follow up with electron microscopic assessment. Mitochondrial structures and cellular structures observed in all the groups were normal. Myofibrillar loss, dilatation of smooth endoplasmic reticulum, mitochondrial swelling or cristalysis was not observed. Intercalated disc degeneration and apoptosis of nucleus was not observed. Therefore, and as a result of our study we did not observe differences between control and EMF groups.

KEY WORDS: Electromagnetic field; Heart; Electron microscopy.

\section{INTRODUCTION}

An increased health risk due to exposure to electromagnetic fields (EMF) at 50 and $60 \mathrm{~Hz}$ has been reported by several authors (Zecca et al.,1998; Seegal et al., 1989; Coelho et al., 1995; Svedenstål \& Johanson, 1995). In vivo studies have dealt with increased tumor incidence, effects on reproduction and development, and neural and behavioral changes (Zecca et al.). Increasing use of electrical appliances in our daily lives that although provide convenience to our lives, EMFs are also harmful. We need to remove from cities, and bring electricity with power of the EMF of $50 \mathrm{~Hz}$ frequency. The band is more than EMF forming devices, increasing the importance of work done on this issue.

Some studies have investigated whether exposure to a magnetic field (MF) poses a risk for cardiovascular morbidity and mortality (Håkansson et al., 2003; Sorahan et al., 2004). A statistically significant relationship was found between exposure to magnetic field and reduced heart rate variability, which leads to certain disorders such as acute myocardial infarcts and cardiac arrhythmia (Savitz et al., 1999). Empirical studies with volunteers show that exposure to a MF may affect the heart's control over the autonomous nervous system, which results in reduced heart rate variability (Graham et al., 2000). Reduced heart rate variability is defined as a risk for acute myocardial morbidity and mortality (Tsuji et al., 1994). This hypothesis was first investigated in high line electrical workers and an increased risk was observed between EMF exposure and acute myocardial infarcts and arrhythmias; however, no increased risk was observed for chronic coronary heart disease and atherosclerosis (Savitz et al.).

\footnotetext{
* Department of Histology and Embryology, Medicine Faculty of Dicle University, Diyarbakır, Turkey.

** Department of Biophysics, Medicine Faculty of Harran University, Sanliurfa, Turkey.

**** Department of Anatomy, Medicine Faculty of Harran University, $S_{s}$ anliurfa, Turkey.

***** Department of Histology and Embryology, Medicine Faculty of Dokuz Eylül University, I'zmir, Turkey.
} 
Electromagnetic fields (EMF) have adverse effects as a result of widespread use of electromagnetic energy on biological systems. Although exposure to EMF is part of the treatment of different diseases, little is known as to their effects on heart. Therefore, the aim of this study was to investigate the effects of EMF on heart ultrastructurally in EMF exposed rats.

\section{MATERIAL AND METHOD}

Animals. The research was designed and implemented according to principles of the Declaration of Helsinki. This experimental research was performed with the approval of the to local ethics committee. Forty five male rats were exposed to $0.25 \mathrm{mT}$ sinusoidal magnetic field for two weeks.

Spraque Dawley rats were obtained from the Medical Science Application and Research Center. All animals were 2 months old at the beginning of the study, weighing 250$280 \mathrm{~g}$, and were fed with Standard pellet food. The rats were divided into three groups of fifteen: Control, sham, and experimental groups. The experimental group was exposed to a $0.25 \mathrm{mT}$ to Extremely Low Frequency magnetic field (ELF$\mathrm{MF})$ in metacrylate boxes $(17 \times 17 \times 25)$. The experimental group $(n=15)$ was exposed to ELF-MF for 14 days, $3 \mathrm{~h}$ a day. The sham group was treated like the experimental group, except for ELF-MF exposure. Treatment of the control group differed from the experimental and sham groups. Animals in the control group were kept in a 14/10 hour light/dark environment at constant temperature of $22 \pm 10 \%$ humidity.

Magnetic field generation and exposure to magnetic field. The magnetic field was generated by a device designed by the researchers that had two pairs of Helmholtz coils of $25 \mathrm{~cm}$ diameter. The frequency of sinusoidal current was 50 Hz. This magnet was constructed by winding 300 turns of insulated soft copper wire with a diameter of $0.85 \mathrm{~mm}$. Coils were placed vertically and horizontally, facing one another. The distance between coils was $25 \mathrm{~cm}$. The average MF intensity was measured as $0.25 \mathrm{mT} \pm 0.01 \mathrm{mT}$ at 12 different points both transverse and axial within the metacarylate cage by using a digital hall effect Gauss meter (Bell 5170, SYPRIS, USA). The measurements were made by an independent researcher who was not involved in the animal experiment. No temperature difference was observed between exposure and sham coils during exposure.

Histological examinations. The animals were euthanized after the final exposure by anesthesia with ketalar $(50 \mathrm{mg} /$ $\mathrm{kg}$, intramuscular). At the end of the experiment, rats were sacrificed; cardiac tissue was fixed in $2.5 \%$ glutaraldehyde.
Routine follow-up was electron microscopic assessment. Sections were evaluated by transmission electron microscope (Carl Zeiss, Inc. Libra 120, Germany).

\section{RESULTS}

At the end of this study the effect of electromagnetic field on heart ultrastructure in electromagnetic field exposed rats was investigated. Histological examination in all three groups was carried out by electron microscope. The control group and other groups in the cellular and mitochondrial structures were observed as normal. Myofibrillar loss, dilation of smooth endoplasmic reticulum, mitochondrial swelling or cristalysis was not observed in all groups. Intercalated disc degeneration and apoptosis of nucleus were not seen (Figs. 1,2,3). We did not observe differences between the groups.

\section{DISCUSSION}

Low frequency magnetic fields are widely used in electrical appliances and different equipment such as television sets, computers and kitchen appliances. Recently, ELF-MF have been considered to be a therapeutic agent and have started to be more commonly used in medicine (Goraca et al., 2010).

Electromagnetic fields have adverse effects on biological systems, as a result of widespread use of electromagnetic energy. In recent years, a large number of multidisciplinary investigations led to the increasing awareness of the existence of multiple effects of MF in biological systems (Ventura et al., 2000). Some studies have investigated whether exposure to a magnetic field poses a risk for cardiovascular morbidity and mortality (Håkansson et al.; Sorahan et al.). Among workers in the electrical industry, statistically significant differences were found between magnetic field exposure and arrhythmia-dependent and acute myocardial infarcts-dependant death. It was shown that, as magnetic field exposure increases, mortality rate increases for these two reasons (Savitz et al.). In a study of employees of the South California Edison electrical utility company, it was reported that major cardiovascular disease rate increased in all workers who are exposed to an electric or magnetic field (Kelsh et al., 1997).

The results of many studies reporting the correlation between MF exposure and heart rate variability are based on empirical studies conducted in laboratories; however, it 


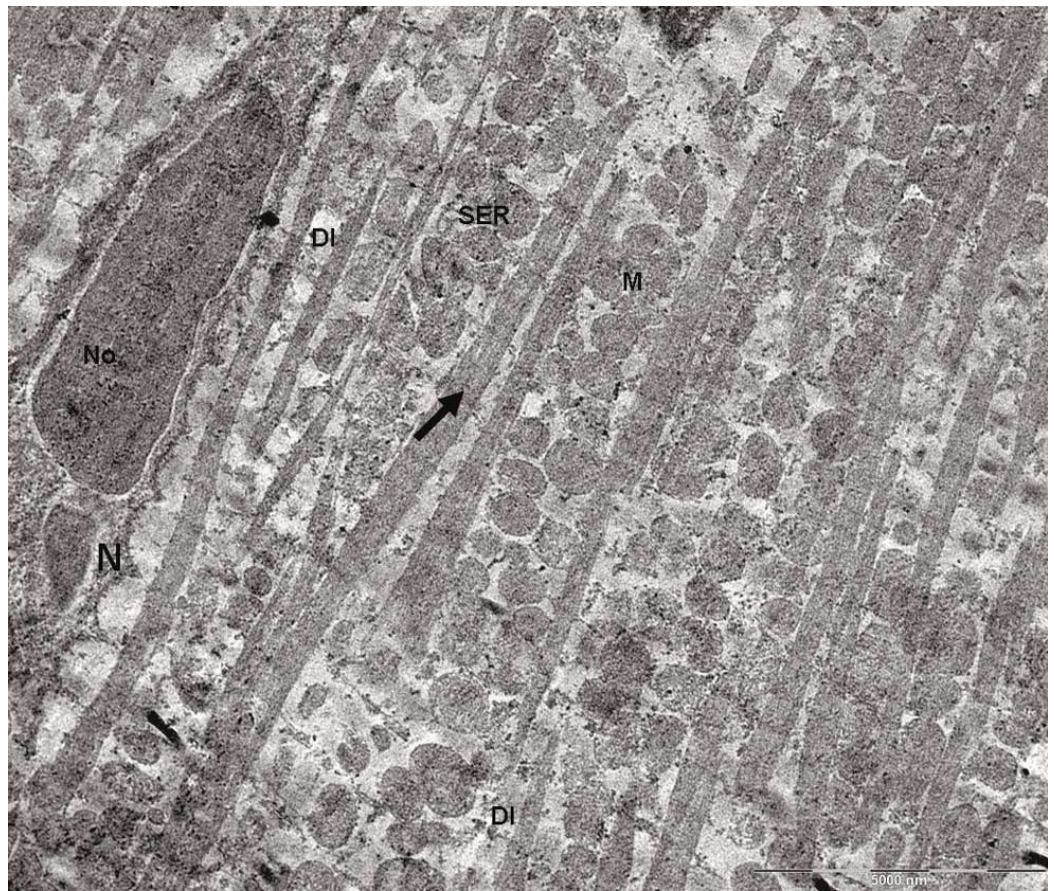

Fig. 1. Electron micrograph of Experimental (Exposed to magnetic field) group. Myofibrils (arrow), Mitochondrias (M), N: Nucleus, No: Nucleolus, Discus intercalaris (DI), SER: Smooth Endoplasmic Reticulum.

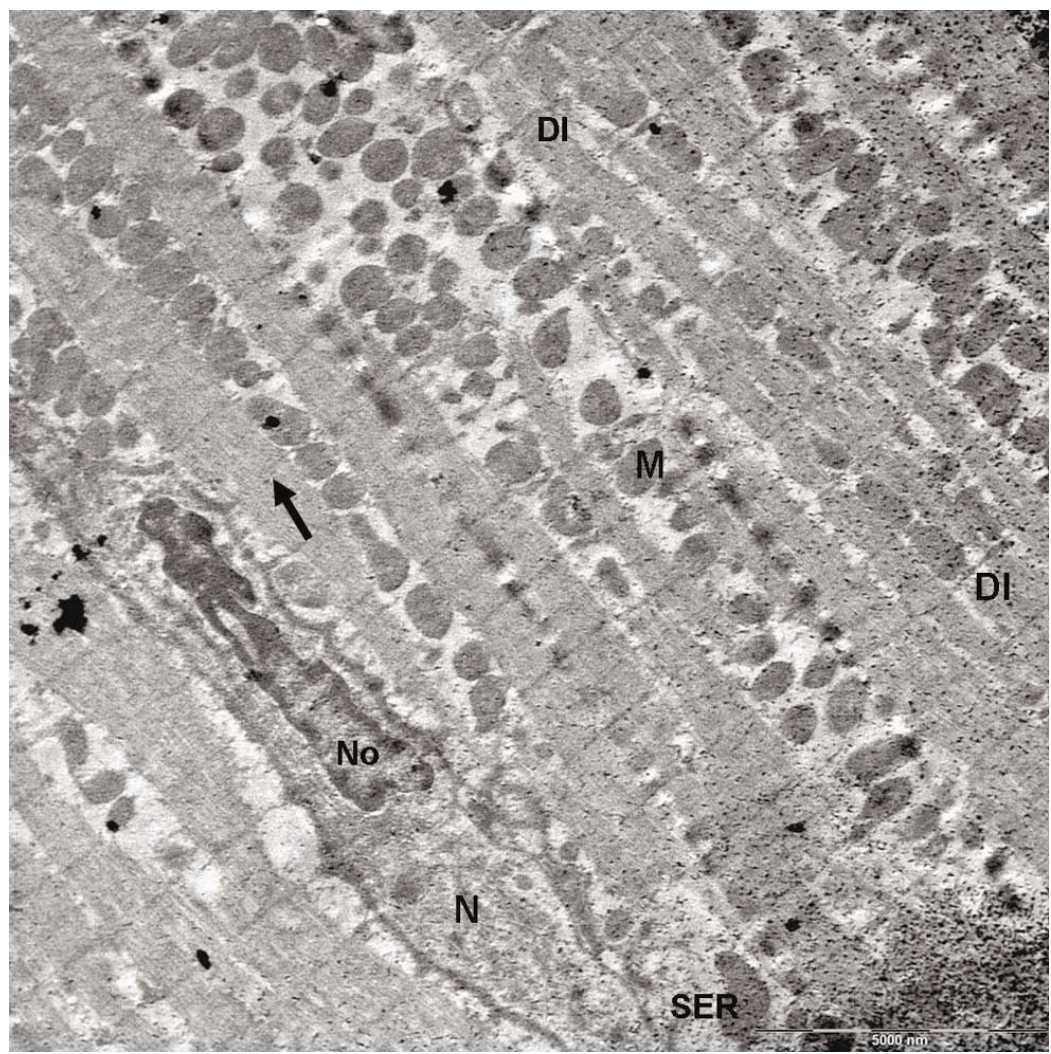

Fig. 2. Electron micrograph of Sham group. Myofibrils (arrow), Mitochondrias (M), $\mathrm{N}$ :Nucleus, No: Nucleolus, Discus intercalaris (DI), SER: Smooth Endoplasmic Reticulum. is not possible to predict arrhythmiadependent death or acute myocardial infarcts-dependent death from acute, reversible, short-term effects on heart rate variability observed under laboratory conditions (Sastre et al., 1998). However, such effects may be caused by cumulative electrical and MF exposure over the course of 5 to 20 years (Savitz et al.). This is because it takes several years for heart rate variability to develop. The response of acute cardiovascular system to an electric and MF is still being analyzed. Therefore, it is important to assign the changes in heart rate variability (Höjevik et al., 1995). Reduced heart rate variability is defined as a risk factor for acute cardiac morbidity and mortality (Lindström et al., 1995). Empirical results show that EMF exposure results in decreased heart rate variability (Graham $e t$ al., 2000).

In this investigation we demonstrated that the exposure of heart of rats to the EMF did not change in the electron microscopic examination. There are limited studies in the literature about the effects of EMF on the ultrastructure of heart (Ronchi et al., 2004; Tayefi et al., 2010). Zecca et al. reported the exposure of adult male Sprague Dawley rats for 8 months ( 8 hrs/day for 5 days/week) to electromagnetic fields of two different field strength combinations: $5 \mathrm{mT}-1 \mathrm{kV} / \mathrm{m}$ and $100 \mathrm{mT}-5 \mathrm{kV} / \mathrm{m}$, and they showed that no histological changes were observed in the collected tissue specimens such as liver, heart, mesenteric lymph nodes, bone marrow, and testes (Zecca et al.). Our finding is consistent with data reported by study of Zecca et al. discussed above.

Ronchi et al., reported the exposed Sprague-Dawley rats to either high (H, 10 $\mathrm{min} /$ day at $200 \mathrm{~V} / \mathrm{m}, 36.1 \mathrm{microT}$ ) or low (L, $2 \mathrm{~min} /$ day at $30 \mathrm{~V} / \mathrm{m}, 11.4 \mathrm{microT}$ ) intensity broad band EMF for 15 days. They showed that electron microscopy revealed sporadic ruptures of mitochondrial cristae in $\mathrm{H}$ hearts (Ronchi et al.). Tayefi et al. showed that under electron microscopy, there were mitochondrial degeneration, reduction in myofibrils, dilated sarcoplasmic reticulum and perinuclear vacuolization in 


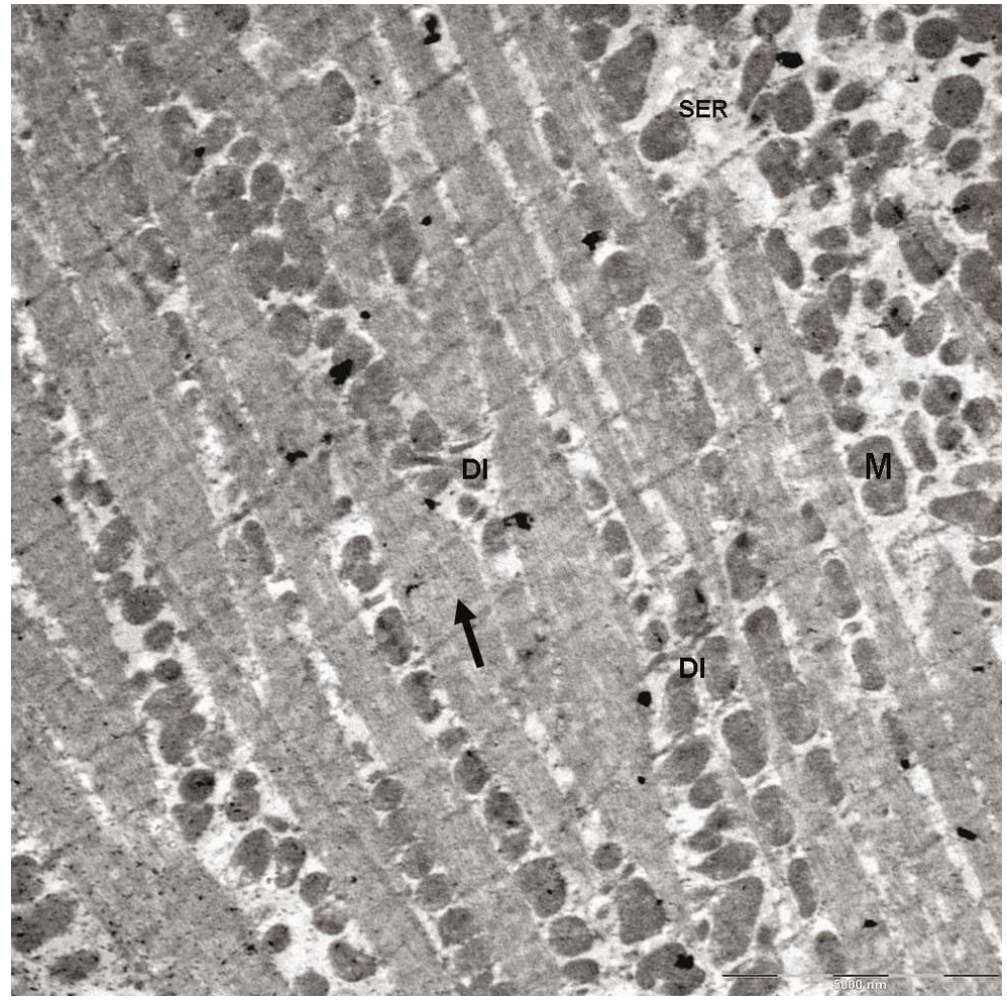

Fig. 3. Electron micrograph of control group.Myofibrils (arrow), Mitochondrias (M), Discus intercalaris (DI), SER: Smooth Endoplasmic Reticulum.

EMF-exposed rats myocardium. This finding was consistent with the findings of Ronchi et al.

In conclusion, extremely low frequency magnetic fields are used in daily life. As a result of our study, in the hearts of rats exposed to extremely low frequency magnetic fields, there was no change detected in the electron microscopic examination. This finding is incompatible with data reported in the studies (Ronchi et al.; Tayefi et al.) discussed above. Administered dose and duration for the EMF's effects on the heart, although important, further studies are needed to demonstrate whether the EMF exposure can induce adverse effects on the heart.

SÖKER, S.; SERT, C.; DENIZ, M.; TEKMEN, I.; AKKUS , M. \& NERGIZ, Y. Efectos de los campos electromagnéticos en la ultraestructura del corazón. Int. J. Morphol., 29(3):960-964, 2011.

RESUMEN: El uso y la comodidad de los aparatos eléctricos en nuestra vida cotidiana cada vez más son causa de efectos perjudiciales debido a los campos electromagnéticos (CEM). El objetivo de este estudio fue investigar el efecto de los CEM sobre la ultraestructura del corazón en ratas. Fueron utilizadas 45 ratas Sprague Dawley, con peso entre 260 y 280 gramos. Las ratas fueron divididas en 3 grupos: control (n: 15); Sham (n:15), y grupo expuesto a CEM (n: 15) durante 14 días, 3 horas por día. Se aplicó niveles de 2,5 gauss al grupo expuesto a CEM, mientras que el grupo de tratamiento simulado en el mismo entorno en jaulas plexiglás se mantuvo durante 14 días 3 horas día, sin exposición a campo electromagnético. Grupo control alimentado en jaulas normales durante 14 días con ciclo luz/oscuridad de 14/10. Al termino de dos semanas las ratas fueron sacrificadas por medio de anestesia Ketalar $50 \mathrm{mg} / \mathrm{kg}$ y el tejido del corazón fijado en gluteraldehido al 2,5. Se realizó seguimiento de rutina con correspondiente evaluación de microscopía electrónica. Las estructuras mitocondriales y celulares observadas en todos los grupos eran normales. No se observó pérdida miofibrilar, tampoco aumento del volumen mitocondrial ni dilatación del retículo endoplásmico liso o cristalysis. No se observó degeneración de los discos intercalados o apoptosis de núcleo. Por lo tanto, y como resultado de nuestro estudio no encontramos diferencias entre los grupos control y CEM.

PALABRAS CLAVE: Campo electromagnético; Corazón; Microscopía electrónica.

\section{REFERENCES}

Coelho, A. M. Jr.; Roger, W. R. \& Easley. S. P. Effects of current exposure to $60 \mathrm{~Hz}$ electric and magnetic fields on the social behavior of baboons. Bioelectromagnetics, Suppl., 3:71-92, 1995.

Goraca, A.; Ciejka, E. \& Piechota, A. Effects of extremely low frequency magnetic field on the parameters of oxidative stress in heart. J. Physiol. Pharmacol., 61(3):333-8, 2010 .

Graham, C.; Cook, M. R.; Sastre, A.; Gerkovich, M. M. \& Kavet, R. Cardiac autonomic control mechanisms in power-frequency magnetic fields: A multistudy analysis. Environ. Health Perspect., 108:737-42, 2000.

Håkansson, N.; Gustavsson, P.; Sastre, A. \& Floderus, B. Occupational exposure to extremely low-frequency magnetic fields and mortality from cardiovascular disease. Am. J. Epidemiol., 158:534-42, 2003.

Höjevik, P.; Sandblom, J.; Galt, S. \& Hamnerius, Y. Ca+2 ion transport through patch-clamped cells exposed to magnetic fields. Bioelectromagnetics, 16:33-40, 1995. 
Kelsh, M. A. \& Sahl, J. D. Mortality among a cohort of electric utility workers, 1960-1991. Am. J. In. Med., 31:534-44, 1997.

Lindström, E.; Lindström, P.; Berglund, A.; Lundgren, E. \& Mild, K. H. Intracellular calcium oscillations in a T-cell line after exposure to extremely -low- frequency magnetic fields with variable frequencies and flux densities. Bioelectromagnetics, 16:41-7, 1995.

Ronchi, R.; Marano, L.; Braidotti, P.; Bianciardi, P.; Calamia, M.; Fiorentini, C. \& Samaja, M. Effects of broad band electromagnetic fields on HSP70 expression and ischemia-reperfusion in rat hearts. Life Sci., 75:1925-36, 2004.

Sastre, A.; Cook, M. R. \& Graham, C. Nocturnal exposure to intermittent $60-\mathrm{Hz}$ magnetic fields alters human cardiac rhythm. Bioelectromagnetics, 19:98-106, 1998.

Savitz, D. A.; Liao, D.; Sastre, A.; Kleckner, R. C. \& Kavet, R. Magnetic field exposure and cardiovascular mortality among electric utility workers. Am. J. Epidemiol., 149(2):135-42, 1999.

Seegal, R. F.; Wolpaw, J. R. \& Dowman, R. Chronic exposure of primate to $60 \mathrm{~Hz}$ electric and magnetic fields: II. Neurochemical effects. Bioelectromagnetics, 10:289-301, 1989.

Sorahan, T. \& Nichols, L. Mortality from cardiovascular disease in relation to magnetic field exposure: Findings from a study of UK electricity generation and transmission workers, 1973-1997. Am. J. Ind. Med., 45:93-102, 2004.

Svedenstål, B. M. \& Johanson, K. J. Fetal loss in mice exposed to magnetic fields during early pregnancy. Bioelectromagnetics, 16:284-9, 1995.

Tayefi, H.; Kiray, A.; Kiray, M.; Ergur, B. E.; Bagriyanik, H. A.; Pekçetin, C.; Fidan, M. \& Ozogul, C. The effects of prenatal and neonatal exposure to electromagnetic fields on infant rat myocardium. Arch. Med. Sci., 6:837-42, 2010.

Tsuji, H.; Venditti, F. J. Jr.; Manders, E. S.; Evans, J. C.; Larson, M. G.; Feldman, C. L. \& Levy, D. Reduced hearth rate variability and mortality risk in an elderly cohort. The Framingham Heart Study. Circulation, 90:878-83, 1994.
Ventura, C.; Maioli, M.; Pintus, G.; Gottardi, G. \& Bersani, F. Elf-pulsed magnetic fields modulate opioid peptide gene expression in myocardial cells. Cardiovasc. Res., 45:1054-64, 2000.

Zecca, L.; Mantegazza, C.; Margonato, V.; Cerretelli, P.; Caniatti, M.; Piva, F.; Dondi, D. \& Hagino, N. Biological effects of prolonged exposure to ELF electromagnetic fields in rats: III. $50 \mathrm{~Hz}$ electromagnetic fields. Bioelectromagnetics, 19(1):57-66, 1998.

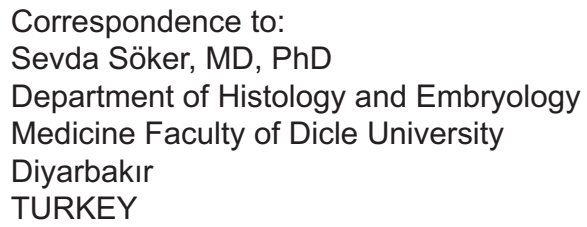

Phone number: 0412 2488001/4441,

Fax number: 04122488440

E-mail: ipeksoker@hotmail.com

Received: 01-02-2011

Accepted: 23-03-2011 